\title{
Reformation: Religious, Political and Social Consequences for Western Society
}

\author{
Humaira Ahmad
}

\begin{abstract}
Reformation was a theological movement in $16^{\text {th }}$ century Europe to reform the Catholic Christianity. Luther, Calvin and Zwingli questioned the authority of dogma and supremacy of the pope in Rome. This led to the formation of hundreds of sects in Western Christianity. Salvation was sought outside the church. Consequently, church was excluded from the cultural life of Western societies. Reformation also gradually established the role of political authority in religious matters.
\end{abstract}

'Reformation' emerged as a theological movement during $16^{\text {th }}$ century in Europe which attempted to change and improve the Catholic Church, and resulted in the establishment of the Protestant Church. This movement was a revolt against the authority of medieval Catholic Church aimed at reforming the church of Christendom and removing its tribulations. ${ }^{202}$ The Reformation was not a sudden upsurge or a reaction to any particular incident. It was the outcome of the Church's excesses spread over decades and numerous factors played important roles in this respect.

The Reformation emerged as a historical consequence from the interaction of many complex cultural forces of Western history. Renaissance was an important factor in creating a fertile soil for Reformation. The spirit of the time even when intending to be hostile, proved friendly. The Renaissance that had raised the ancient classical world from its grave, was not itself opposed to the Catholic Church, but the reason it educated and the temperament it formed, the literature it produced and the languages it loved, the imagination it cultivated and the new sense of beauty it created, there were forces of subtle hostility to the system that had been built upon the ruins of classical antiquity. ${ }^{203}$

The renaissance leaders rejected many of the attitudes and ideas of the Middle Ages. They emphasized people's responsibilities and duties to the society in which they lived, rejecting the older beliefs of praying to God. Renaissance thinkers paid more attention to the study of humanity than to theology. ${ }^{204}$

202 Johan Herman Randall, Making of the Modern Mind (New York: Columbia University Press, 1926), 143.

203 A. W. Ward, G.W. Prothero., Stanley Leathes, (ed.) The Cambridge Modern History, vol:2 The Reformation (London: Cambridge University Press,1902), 342

${ }^{204}$ Lewis W. Spitz, The Renaissance and Reformation Movements (Chicago: Rand McNally \& Company, 1972) \& Charles B. Schmitt, Quentin Skinner \& Eckhard Kesssler (ed.), The Cambridge History of Renaissance Philosophy, (NY: Cambridge University Press, 1988), The Renaissance : Essays in Interpretation, (ed.) (New York: Methuen \& Co. Ltd.), 34, 155, 
The invention of movable type in the mid 1400's helped to spread learning and an increased number of people outside the clergy gained education during the Renaissance. The study of scriptures allowed the people to know about the Church in which changes had been made through centuries. ${ }^{205}$ The scientific discoveries of this period patently contradicted both the Bible and the teachings of the Church further weakened papal and clerical authority. ${ }^{206}$

Reformation movement was the historical outcome of Renaissance, primarily aimed at reviving the coalition of religion and politics which was characteristic of the Middle Ages and weakened during the Renaissance period. ${ }^{207}$ To put an end to the dominance of popes was among the major themes of Reformation. Individual interpretation of the Bible was allowed and was used as the tool to express personal opinion. ${ }^{208}$ In order to free the state from the influence and dominance of the church, the term 'divine right of the king' was introduced. ${ }^{209}$

The foundation stone for political authority and 'divine right of king' was laid down long before the Reformation. During the Renaissance, Dante raised voice for the supreme authority of monarchs. ${ }^{210}$ Marsiglio of Padua, William of Ockham, John Wycliffe and John Hus were also among early thinkers, who questioned the absolute political realm of the Roman Catholic Church.

Marsiglio of Padua questioned the authority of the Pope and supported autonomous political unit, and was of the view that law was ultimately derived from the people or from the more influential of them rather than the church. He was one of the first to raise the voice for secular government elected by the legislative authority. His criticism of papacy and of canon law was corrosive. He was of the view that the state is the source of law and its law has to be obeyed not only because it is the only rule to be endowed with coercive power but because it is in itself the expression of justice. ${ }^{211}$

305. \& Marvin Perry, et'al (ed.), Western Civilization: Ideas, Politics \& Society, vol: 1 (Geneva: Houghton Mifflin Company, 1989), 264-274.

${ }^{205}$ Ibid. \& De Lamar Jensen, Renaissance Europe: Age of Recovery and Reconciliation, (Massachusetts: D.C. Heath and Company, 1981), 7-37.

${ }^{206}$ Ibid. \& Western Civilization: Ideas, Politics \& Society, 267-270.

207 Reformation created a new World order as Toby Huff has written that, "The Reformation claimed to replace a corrupt modern order by the true primitive order... It proved to have many new elements, different in structure not only from those which had prevailed in the Middle Ages, but also from those which had characterized the apostolic community of the early church in Benjamin Nelson, "Conscience and the Making of Early Modern Cultures: Beyond Max Weber", in On the Roads to Modernity, ed. Toby E. Huff (New Jersey: Rowman and Littlefield, 1981), 75.

208 Johan Herman Randall,166.

${ }^{209}$ Lawrence C. Wanlass, Gettel's History of Political Thought (London: George Allen \& Unwin LTD, 1924), 157.

${ }^{210}$ Ernest Bresiach, Renaissance: Europe 1300-1517 (New York: McMillan Publishing, 1973), 25. \& Gettel's History of Political Thought, 127.

211 Vivian Hubert Howard Green, Renaissance and Reformation: A Survey of European History Between 1450-1660 (London: Edward Arnold Publishing, 1974), 23. 
William of Ockham put theological questions deviating from earlier beliefs and doctrines of Christianity. He emphasized the limitations of papal power and developed the principle of political freedom and toleration. ${ }^{212}$

By providing his countrymen with an English translation of the Bible, Wycliffe enabled them to see for themselves the great differences between the simplicity of early Christianity and the power and wealth of the church of the late middle ages. He attacked the indulgences of popes and demanded that church property be seized and managed by the secular governments. Supporting Marsiglio that the Church was originally a community of equals, he denied the authority of the pope over all Christendom and preached instead a religion of personal piety and the universal priesthood of believers. ${ }^{213} \mathrm{He}$ was known as the man who gave the concept of bringing religion directly to the people and for this he translated the Bible. He denounced the pope as antichrist and challenged a number of accepted beliefs. ${ }^{214}$ John Hus was a follower of John Wycliffe and was burned to death due to his revolt against the church. He was also of the view that the property of the Church must be reduced and that the church has no right to own property. ${ }^{215}$

Martin Luther of Germany (1483-1546), John Calvin of France (1509-1564) and Ulrich Zwingli of Switzerland (1484-1531) were the main advocates of the Reformation. $^{216}$

Martin Luther was a German priest and the originator of the Reformation movement. He declared that popes are the ones who corrupted the Church. ${ }^{217}$ His primary concern was the religious one and that he wanted to reform the society as a whole only by preaching the gospel and making man aware of his ethical duties. ${ }^{218}$ However, the dark side of his philosophy was that he considered man as wicked and prone to sin.

"We are the children of wrath and all our works and intentions and thoughts are nothing at all in balance against our sins... no amount of good works could atone for the sins--each an insult to an infinite deity--committed by the best of men. Only the redeeming sacrifice of Christ--the suffering and the death of the Son of the God--could atone for man's sins; and only belief in that divine atonement can save us from hell. It is this faith, that "justifies" --makes a man just despite his sins and eligible for salvation." 219

\footnotetext{
${ }^{212}$ Steven Ozment, The Age of Reforms 1250-1550 (New Haven: Yale University Press, 1980), 18

213 Harold .J. Grimm, The Reformation Era 1500-1650, (New York: The Macmillan Company, 1954), 43. \& Will Durant, The Story of Civilization, "The Reformation: A History of European Civilization from Wyclif to Calvin 1300 - 1564 (New York: Simon \& Schuster, 1957), 11. \& John H. Randall, 146.

${ }^{214}$ V.H.H. Green, 20, \& Will Durant, 11.

${ }^{215}$ Will Durant, 14.

${ }^{216}$ Vivian Hubert Howard Green, Steven Ozment, Will Durant, Harold .J. Grimm.

${ }^{217}$ Ibid., 351.

${ }^{218}$ Harold .J. Grimm, 90.

${ }^{219}$ Will Durant, 373.
} 
He developed a new theology on the issue of Salvation. He arrived at the conclusion that man is justified by faith alone, that God freely forgives sins, without taking man's merits into consideration. ${ }^{220}$ This highly significant interpretation, that grew out of Martin Luther's own experience and which he found substantiated in the writings of St. Augustine, marked the turning point of his career, and eventually brought him in conflict with the church. ${ }^{221}$

Luther did not intend the gradual reform within the old faith but a fundamental recasting of traditional doctrines and practices. Luther also revived the dark debates and narrow theological interests of the middle ages. ${ }^{222}$ For Luther, to endow man with complete freedom of will in morality and religious matters ascribing truly divine powers to him. ${ }^{223}$

He believed that the faith of a Christian had nothing to do with politics. The duty of a Christian was simply to obey constituted authority. Turning to the princes, Luther confirmed the righteousness of their power. ${ }^{224} \mathrm{He}$ was not a political thinker and his limited experiments in this field were best regarded as an attempt to accommodate the political realities of his time. For consolidation of the Reformation movement, the full support of German princes and magistrates was essential and his confirmation in the righteousness of princes in their powers enabled him to get that support. $^{225} \mathrm{He}$ had drawn a distinction between the spiritual and the worldly government of society. According to his theory, God's worldly government is effected through kings, princes and magistrates through the use of the sword and the civil law. Popes have no authority concerning the affairs of the world. ${ }^{226}$

Following points can be identified that underlie Luther's confused political theology:

$>$ Christian ethics is grounded in the doctrine of justification by faith alone

$>$ All Christians have a civic and social responsibility to perform. Some Christians may discharge these responsibilities by holding public office

$>$ The state has been divinely ordained to achieve certain purposes, which the church can not and should not attempt to achieve. In other words, their spheres of influence and authority are different and must not be confused

$>$ God rules the church through Gospel but is obliged to rule the sinful world through law, wisdom, natural law and coercion ${ }^{227}$

\footnotetext{
${ }^{220}$ Ozment, 375.

${ }^{221}$ Grimm, 91.

${ }^{222}$ Ozment, 1250-1550, 292.

223 Ibid.,301.
}

224 Lutheran Reformation resulted in an alliance of state and church in which former was subservient to the latter. In effect, therefore Lutheranism, made a total surrender of the practical life of the individual to the state control. J. Bronowski, The Western Intellectual Tradition (New York: Harper \& Brothers Publishers, 1960,) 89.

${ }^{225}$ Alister E. McGrath, Reformation Thought: an Introduction (Oxford, UK; Cambridge, MA: B, Blackwell, 1988), 146.

${ }^{226}$ Ibid., 142 .

${ }^{227}$ Ibid., 145-146. 
Luther's political theory clearly supported the monarchy. ${ }^{228}$ As Machiavelli freed the state from the consideration of moral law, Luther likewise freed it from control of the Church. Is it not the duty of the state, he argued, to check and control all forms of domination injuring the welfare of the people? Thus he won the sympathy of the multitude by his stern attitude to capitalism, luxury and immorality. ${ }^{229}$ In Luther's words, "neither Pope, nor Bishop, nor any man has a right to dictate even a syllable to the Christian without his own consent; any other course is pure tyranny. ${ }^{230}$

John Calvin, who belonged to Geneva, was the founder of the Reformation movement in France and other European countries. John Calvin adopted austerity against extravagance in dress and entertainment. Drama, art and drunkenness were censored. $^{231}$

For him, the Church and state were both divine and designed by God to work in harmony as the soul and body of one Christian society. The Church should regulate all details of faith, worship and morals. The state as the physical arm of the church should enforce these regulations. The ideal government would be a theocracy and the reformed church should be recognized as the voice of God. All the claims of the popes for supremacy of the church over the state were renewed by Calvin. ${ }^{232}$

Ulrich Zwingli also contributed to the reformation. He believed that ultimate ecclesiastical authority is the Christian community and the local assembly of believers under the sole lordship of Christ and the divinely inspired scriptures that bear witness to redemption through him. This authority is exercised on behalf of the community through the duly constituted organs of civil government acting in accordance with the scriptures. Only that which Bible commands or for which distinct authorization can be found in its pages is binding or allowable. ${ }^{233}$

Zwingli formulated his doctrine while agreeing with Martin Luther that man can earn salvation by good works, but must believe in redeeming efficacy of Christ's sacrificial death. ${ }^{234} \mathrm{He}$ also laid great emphasis upon providing the people with the Bible in their native language. ${ }^{235}$ Zwingli identified the word of God with the scriptures when he held to be inspired and infallible. The word of god is certain and cannot fail; it makes itself plain and illumines the human soul with all salvation. ${ }^{236}$ $\mathrm{He}$ ordered that marital matters which were previously settled by a special court

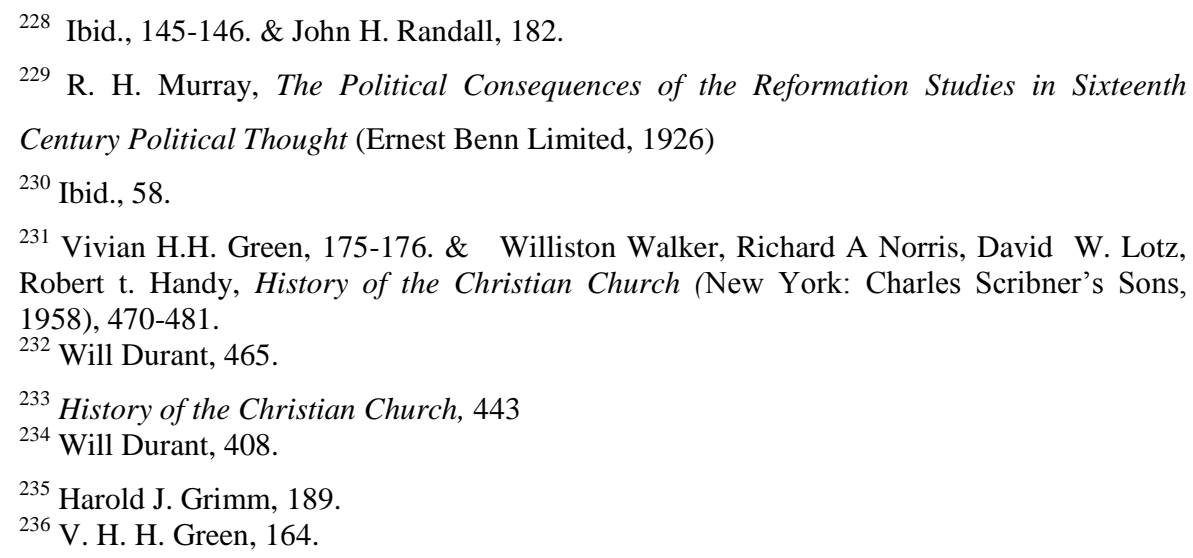


under the administration of the church, be transferred to civil court consisting of representatives of both state and Church. Gradually all matters concerning private morals were referred to this court. ${ }^{237}$

He was more interested in political reforms than religious reforms. The ideas of Zwingli were put into legal reforms in Switzerland. Accordingly, he upheld the right of the community to regulate its religious as well as civil life. In this way, Church and state were merged into a single system controlled by its political agencies. Zwingli believed that he was God's prophet for spreading the faith, and was prepared to use political means for carrying out the divine will in Zurich and whole of Switzerland. ${ }^{238}$

All these reformers grounded the authority of scripture in its relation to the words of God. The reformers insisted that the authority of popes must be subordinate to the scripture. Luther declared that the distinction between the spiritual and temporal powers must be abolished and every believing Christian must have the right to interpret the scripture. He said:

"Their claim that only the pope may interpret scripture is an outrageous ancient fable. The Romanists must admit that there are many among us good spirit, understanding word, and mind of Christ. Why then should we reject the word and understanding of good Christians and follow the pope, who has neither faith nor the spirit" ${ }^{\text {239. }}$

Reformation movement with its different objectives, worked at three levels. The first was the purely religious one. For Luther, this meant that everyone had to decide in his own conscience how the words of God should be read. The second level was the revolt against the splendor with which papacy had come to surround itself. And the third level was the development of political and social ideas. ${ }^{240}$

The impact of the Reformation movement was manifold. Europe was divided religiously. The division of the Western Christendom into several churches was the foremost consequence of the Reformation. The centrality of the Catholic Church was destroyed, and the universal Church gave way to national churches. ${ }^{241}$ While the political authorities precluded the formal recognition of more than one church, the existence of several religious perspectives (bitterly opposing one another) surely curtailed the public as well as private significance of religion in Europe. ${ }^{242}$

In the words of Bronowski, "It gave to Europe as a result of the religious wars which stemmed from it, the political shape which more or less, has kept ever since. And it supplied the European mind with a new ethos, a whole new sensibility and a stock of novel political, social and economic ideas." 243 Concluding the discussion on Reformation Will Durant is of the opinion that, "The reformation rendered two

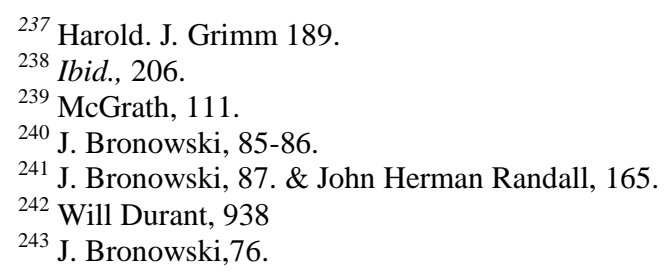


services to the Enlightenment: it broke the authority of the dogma, generated a hundreds sects that would formerly have died at the stake and allowed among them such virile debate that reason was finally recognized as the bar before which all sects had to plead their cause unless they were armed with irresistible physical force. In that pleading, that attack and defense, all sects were weakened, all the dogmas; and a century after Luther exaltation of faith Francis Bacon proclaimed that knowledge is power. In that same 17th century thinkers like Descartes, Hobbes, Spinoza and Locke offered philosophy as a substitute or basis for religion. In the eighteenth century Helvetius Hollbach proclaimed open atheism, and Voltaire was called a bigot because he believed in God. This was the challenge that Christianity failed in a crisis far more profound than the debate between the Catholic and the Protestant version of the medieval creed."244

The exercise of political authority in the realm of religion was more firmly established at the end of the sixteenth century than it had been at the beginning. The support provided by Luther to the princes resulted in an alliance of church and state in which the former was subservient to the latter. ${ }^{245}$ Therefore, Luther made a total surrender of the practical life of the individual to the state control. Luther himself declared, "Our teachings have accorded to secular sovereignty the plentitude of the rights and powers and thus doing what the popes have never done nor wanted to do.",246

The political theology of Martin Luther was clearly about religious freedom. According to him ethics is grounded in the doctrine of justification by faith alone, the state has been divinely ordained to achieve certain purposes, which the church cannot and should not attempt to achieve. In other words, their spheres of authority are different and must not be confused. ${ }^{247}$

The fundamental doctrine of the Reformation movement led to the growth of marked individualism which resulted in grave social, political, and economic conflicts. It led ultimately to the growth of individual liberty and democracy. The reformers preached the equality of man to follow his conscience and to attain salvation in his own way. This individual freedom from a religious point of view had its political repercussions too and led to the growth of democracy. ${ }^{248}$ Salvation was sought outside the church. Priesthood was made unnecessary in finding supreme authority in Bible $^{249}$ and the rational interpretation of the scripture was allowed.

Reformation broke down the authority of universal church and political tyranny was promoted by Luther which ultimately led to nationalism. In the next upcoming events, thirty years war and religious wars helped to define the future political shape of Europe on the basis of independent and sovereign nation states. ${ }^{250}$ Toleration and the recognition of the authority of the individual reason and

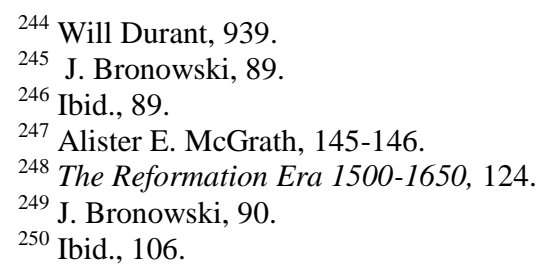


conscience did spring from the Reformation. It fostered both political and economic individualism and allowed greater freedom of interpretation of the faith and, perhaps because of this, it helped the slow drift from religious to secular individualism. $^{251}$

Finally, Reformation, while adding nothing to the content of education, contributed greatly to its spread. It led Europe to learning and in fostering the new science. Leiden in Holland and Geneva University are the products of Reformation. ${ }^{252}$

Reformation was a step forward towards modern times. Martin Luther laid down the foundations of ethos of modernity, "Reformation was a movement which originated in a desire to purge a unified church torn asunder and divided against itself existing a new world... Martin Luther and his followers, intending return to the old, helped to create a new world, a new world not so much in space as in time-----the world of modern times.",253

${ }^{251}$ Ibid \& Vivian H.H Green, 124.

${ }^{252}$ John Herman Randall, 169.

${ }^{253}$ J. Bronowski, 106. 